\title{
Kompetencja komunikacyjna menedżera jako czynnik skutecznego zarządzania przedsiębiorstwem
}

\section{Wstęp}

Kompetencją komunikacyjną określić można znajomość werbalnych i niewerbalnych zasad skutecznego komunikowania się nadawcy i odbiorcy oraz umiejętność efektywnego zastosowania tych zasad w konkretnej interakcji. Tymczasem, aby odnieść „sukces komunikacyjny” w określonej działalności, np. w wychowaniu, doradztwie, marketingu, negocjacjach, „należy ponadto posiadać znajomość stosowania odpowiednich form, metod i środków komunikowania, a także umiejętność przetwarzania informacji naukowo-technicznej i naukowo-humanistycznej na język odbiorcy, dostosowując treść tej informacji do jego możliwości percepcyjnych"1. Kompetencję tę kształtuje się przez całe życie, ale jej podstawowych zasad uczy się między 10. a 12. rokiem. Jej poznanie i stosowanie może być przydatne menedżerowi w doskonaleniu umiejętności pełnienia ról kierowniczych oraz sprawności kierowania personelem w organizacji.

W niniejszym artykule przybliżono czytelnikowi pojęcie komunikowania, formy komunikacji w przedsiębiorstwie oraz najważniejsze zasady komunikowania werbalnego i niewerbalnego decydujące o skutecznym zarządzaniu przedsiębiorstwem.

\footnotetext{
${ }^{1}$ Por. kategorię „składników kompetencyjnych” w podręczniku Z.J. Przychodzenia pt. „Podstawy dydaktyki doskonalenia zawodowego w rolnictwie" (Wydaw. SGGW, 1992, s. 43-45) $\mathrm{i}$ „kompetencję humanistycznq" w jego najnowszym artykule pt. „Humanistyka w edukacji studentów medycyny weterynaryjnej”, zamieszczonym w pracy „Kształtowanie kadr weterynaryjnych w Polsce - teraźniejszość i przyszłość” (pod red. naukową W. Klucińskiego, J. Kity, N. Pospiesznego, Wydaw. SGGW, Warszawa 2004), a także H. Hamer: Perfekcyjne wystapienie publiczne (W: ,Roczniki Katedry Nauk Humanistycznych Szkoły Głównej Gospodarstwa Wiejskiego" z serii „Doradztwo i komunikowanie w działalności przedsiębiorczej”. Tom II. Praca zbiorowa pod red. naukową Z.J. Przychodzenia, Wydaw. SGGW, Warszawa 2004, s. 106-116, i tamże: U. Korniluk: Komunikowanie w procesie wychowawczym. Wartości domu rodzinnego i stopień ich preferencji wyrażony w nieakceptującej postawie młodzieży szkolnej, s. 117-125).
} 


\section{Pojęcie komunikowania}

W literaturze przedmiotu istnieją trzy terminy: komunikowanie, komunikowanie się i komunikacja. Traktowane są najczęściej jako synonimy. Wszystkie mają wspólne pochodzenie etymologiczne; pochodzą od łacińskiego terminu communicatio (czasownik commumunicare = zawiadamiać, być $\mathrm{w}$ relacji z kimś, uczestniczyć w czymś), który ma dwa podstawowe znaczenia. Po pierwsze, określa udzielanie informacji, przekazywanie wiadomości, po drugie - oznacza współudział, uczestnictwo, obcowanie. Łaciński rzeczownik communicatio został wchłonięty przez języki nowożytne w postaci communication i oznaczał początkowo „wejście we wspólnotę, „utrzymywanie z kimś stosunków”, później „komunie”, „uczestnictwo”, wreszcie od XVI wieku, w związku z rozwojem poczty i dróg, nadano mu znaczenie: „transmisja”, ,przekaz”. Termin communicatio może mieć przynajmniej trzy znaczenia:

- przemieszczanie ludzi i przedmiotów w przestrzeni za pomocą środków transportu (pociąg, samochód, samolot);

- przekazywanie informacji na odległość za pomocą technicznych środków przekazu (telegraf, radio, telewizja, nowe media);

- bezpośrednia relacja interpersonalna.

W naukach humanistycznych, głównie socjologii i psychologii społecznej, gdy mówimy o „komunikowaniu się”, „komunikowaniu” czy „komunikacji”, mamy na myśli to drugie znaczenie, a mianowicie komunikowanie treści symbolicznych. Każdy z tych trzech terminów ma inny odcień znaczeniowy. „Komunikowanie się" określa proces, w którym ludzie mogą bezpośrednio wymieniać sygnały za pomocą werbalnych i niewerbalnych środków przekazu. Dochodzi do wymiany ról między mówiącym i przysłuchującym się. W „komunikowaniu" bezpośredni kontakt nie istnieje, natomiast komunikacja dokonuje się za pomocq mediów, środków społecznego komunikowania. Tak więc „komunikowanie" wyraża jednokierunkowość relacji (nadawca mówi - odbiorca słucha), „komunikowanie się" oznacza dwukierunkowość (nadawca i odbiorca pełnią podwójne role), a komunikacja wyraża „przepływ" (informacje krążą w systemie).

Łaciński termin communicatio jest związany ściśle z innym łacińskim słowem - communitas, które oznacza wspólnotę ludzi, koleżeństwo i sprawiedliwość w ich wzajemnym odnoszeniu się do siebie. Sens terminu „komunikacja” sugeruje zatem, że celem komunikowania nie jest tylko wyrównywanie poziomu wiadomości między nadawcą i odbiorcą informacji (wymiana znaczeń), ale także budowanie porozumienia, łączności, współudziału, czyli tworzenie 
wspólnoty ${ }^{2}$. Termin ten przybliżą poniższe definicje, które można znaleźć $\mathrm{w}$ literaturze poruszającej zagadnienia związane $\mathrm{z}$ komunikowaniem interpersonalnym.

Komunikowanie - to proces, w którym ludzie dążą do dzielenia się znaczeniami za pośrednictwem przekazywanych komunikatów ${ }^{3}$.

Komunikowanie - to tworzenie, mniej lub bardziej trwałych, międzyludzkich więzi za pomoca języka oraz innych zachowań symbolicznych ${ }^{4}$.

Komunikowanie - to mechanizm, dzięki któremu stosunki między ludźmi mogą istnieć $\mathrm{i}$ rozwijać się, tj. wszystkie symbole umysłu, łącznie ze środkami przekazywania ich w przestrzeni i przechowywania w czasie $\mathrm{e}^{5}$.

Komunikowanie interpersonalne - to podejmowana w określonym kontekście wymiana werbalnych, wokalnych i niewerbalnych (symboli) w celu osiągnięcia lepsżego poziomu współdziałania ${ }^{6}$.

Komunikowanie interpersonalne - to proces przekazywania $\mathrm{i}$ odbierania informacji pomiędzy dwiema osobami lub pomiędzy małą grupą osób, wywołuje określone skutki i rodzaje sprzężeń zwrotnych ${ }^{7}$.

\section{Formy komunikacji w przedsiębiorstwie}

Menedżer kierujący przedsiębiorstwem wykorzystuje dwie formy komunikowania werbalnego: ustną i pisemna. Komunikacja ustna ma miejsce w toku bezpośredniej rozmowy, dyskusji grupowych, rozmów telefonicznych i inne okoliczności, w których słowo mówione jest wykorzystywane do przekazywania treści. W komunikacji pisemnej do przekazywania informacji wykorzystuje się słowo pisane, sporządza się notatki, listy, sprawozdania i inne pisma urzędowe. Każda $\mathrm{z}$ nich ma swe szczególne zalety i wady, co zawarto w tabeli 1 . Pewne wady zauważone przez ich autora mogą być eliminowane przy zastosowaniu bogatego zestawu form komunikowania, np. mieszanego, wizyjnego. Wybór najlepszej formy komunikacji zależał będzie od sytuacji.

\footnotetext{
${ }^{2} \mathrm{M}$. Filipiak: HOMO COMMUNICANS - wprowadzenie do teorii masowego komunikowania. Wydaw. UMCS, Lublin 2003, s. 12-13.

${ }^{3}$ K. Burakowski: Komunikowanie społeczne. Wydaw. Akademia Obrony Narodowej, Warszawa 1999, s. 8.

${ }^{4}$ J. Waszkiewicz: Jak Polak z Polakiem. Wydawnictwo Naukowe PWN, Warszawa-Wroclaw 1997, s. 26.

${ }^{5}$ T. Goban-Klas: Public relations. Wydaw. Business Press, Warszawa 1997, s. 91.

${ }^{6}$ Z. Nęcki: Komunikacja międzyludzka. Wydaw. Antykwa, Kraków 2000, s. 98.

${ }^{7} \mathrm{~W}$. Głodowski: Komunikowanie interpersonalne. Wydaw. HANSA COMMUNICATION, Warszawa 2001, s. 20.
} 
Tabela 1

Porównanie form komunikacji interpersonalnej

\begin{tabular}{|l|l|l|}
\hline Forma & \multicolumn{1}{|c|}{ Zalety } & \multicolumn{1}{c|}{ Wady } \\
\hline Ustna & $\begin{array}{l}\text { 1. Sprzyja zwrotnej reakcji i wy- } \\
\text { mianie poglądów } \\
\text { 2. Latwa w użyciu }\end{array}$ & $\begin{array}{l}\text { 1. Może być niedokładna } \\
\text { 2. Nie zostawia trwałego zapisu }\end{array}$ \\
\hline Pisemna & $\begin{array}{l}\text { 1. Przeważnie jest dokładniejsza } \\
\text { 2. Zostawia zapis }\end{array}$ & $\begin{array}{l}\text { 1. Nie sprzyja zwrotnej reakcji i wy- } \\
\text { mianie poglądów } \\
\text { 2. Trudniejsza i bardziej czaso- } \\
\text { chłonna } \\
\text { 3. Brak bezpośredniości } \\
\text { 4. Wysokie ryzyko nieporozumień }\end{array}$ \\
\hline
\end{tabular}

Źródło: Opracowanie własne na podstawie R.W. Griffin: Podstawy zarządzania organizacjami. Wydawnictwo Naukowe PWN, Warszawa 1998, s. 558.

Menedżer powinien rozważyć użycie formy ustnej w sytuacji, gdy wiadomość ma charakter osobisty, nierutynowy i zwięzły. Jeśli treść przekazu jest bardziej bezosobowa, rutynowa i dłuższa, wówczas lepsza będzie forma pisemna. Menedżer może również łączyć różne formy przekazu, aby wykorzystać zalety każdego $z$ nich.

Poza obu przedstawionymi formami komunikacji interpersonalnej menedżerowie zajmują się innymi odmianami komunikowania się $w$ organizacji. Każda $z$ nich wymaga komunikacji ustnej lub pisemnej. Do form komunikacji grupowej i organizacyjnej należą komunikacja pionowa i pozioma, sieci komunikacyjne oraz „winorośl”. Komunikacja pionowa to komunikacja, która płynie w górę i w dół organizacji, zwykle wzdłuż linii służbowego podporządkowania; odbywa się pomiędzy menedżerami i ich podwładnymi i może obejmować kilka odrębnych szczebli organizacyjnych. Komunikacja w górę składa się $\mathrm{z}$ wiadomości od podwładnych do zwierzchników. Typowe treści przekazywane przez komunikację biegnąca $z$ dołu do góry to wnioski, prośby oraz informacje, które w opinii menedżerów niższego szczebla mogą mieć znaczenie dla menedżerów wyższego szczebla, odpowiedzi na żądania menedżerów wyższego szczebla, sugestie, skargi i informacje finansowe. Badania wykazały, że komunikacja „ku górze” jest bardziej podatna na zakłócenia niż komunikacja w odwrotnym kierunku. Podwładni mogą wstrzymywać lub zniekształcić taką informację, która stawia ich w złym świetle. Komunikacja w dół ma miejsce wówczas, gdy informacja spływa po szczeblach hierarchii od przełożonego do podwładnych. Typowa treść takich przekazów to dyrektywy dotyczące sposobu wykonania określonych zadań, przydzielanie nowych obowiązków, zwrotna ocena osiagnięć, a także ogólne informacje, które w opinii menedżera wyższe- 
go szczebla mogą mieć pewną wartość dla menedżera szczebla niższego. Komunikacja pionowa może i zwykle powinna być dwukierunkowa. System wewnętrznego komunikowania się w organizacji powinien być stale doskonalony, ponieważ jest jednym $\mathrm{z}$ ważniejszych składników wewnętrznej reputacji organizacji.

$\mathrm{Z}$ badań przeprowadzonych w latach 90 . nad wewnętrzną komunikacją w 300 organizacjach amerykańskich wynika kilka wniosków, które wydają się prawdziwe również w odniesieniu do polskich warunków. Okazało się, że:

- zdecydowana większość pracowników oczekuje i ceni sobie najbardziej wymianę informacji z przełożonymi w kontaktach bezpośrednich (twarzą w twarz),

- podwładni niezbyt wysoko oceniają umiejętności komunikowania się kierowników niższych szczebli, natomiast kierownicy szczebli wyższych i najwyższego według nich pozostają poza zasięgiem szeregowych pracowników,

- stosunkowo wysoko członkowie organizacji oceniaja publikacje informacyjne, ale mimo to nie jest to preferowana forma komunikowania się 8 .

$\mathrm{O}$ ile komunikacja pionowa obejmuje zwierzchnika i podwładnego, komunikacja pozioma angażuje kolegów i osoby na równorzędnych stanowiskach w organizacji; moźe obejmować osoby z kilku różnych jednostek organizacyjnych. Komunikacja pozioma ma miejsce częściej pomiędzy menedżerami niż innymi pracownikami i służy różnym celom. Ułatwia koordynację pomiędzy niezależnymi jednostkami. Może być wykorzystywana do wspólnego rozwiązywania problemów, gdy np. dwóch kierowników zakładów przygotowało wspólnie nową metodę poprawy wydajności. Odgrywa ważną rolę $\mathrm{w}$ pracy zespołów roboczych, których członkowie wywodzą się z różnych wydziałów.

Komunikowanie się członków grupy w przedsiębiorstwie odbywa się według różnych wzorców, które określa się mianem sieci komunikacyjnych. W badaniach sieci komunikacyjnych zidentyfikowano pięć podstawowych typów sieci w grupach 5-osobowych, a mianowicie: „koło u wozu”, „wzorzec litery Y”, „łańcuch”, „okrag" i „każdy z każdym”. Różnią się one przepływem informacji, pozycją przywódcy i skutecznością w wypełnianiu różnych typów zadań. Przykładem sieci najsilniej scentralizowanej jest „koło u wozu”, ponieważ jedna osoba otrzymuje i przekazuje całość informacji. Najbardziej zdecentralizowana jest sieć wszystkich kanałów, a więc „każdy z każdym”. Menedżerowie mogą dążyć do stworzenia sieci zdecentralizowanych, gdy zadania

${ }^{8}$ B. Sobkowiak: Public relations jako forma komunikowania masowego. W: Studia $\mathrm{z}$ teorii komunikowania masowego. Red. naukowa B. Dobek-Ostrowska. Wydaw. Uniwersytetu Wrockwskiego, Wrocław 1999, s. 75. 
grupy są złożone i nierutynowe (np. podjęcie ważnej decyzji dotyczącej strategii organizacji). Jeżeli zadania grupy są stosunkowo proste i rutynowe, to największą skuteczność i dokładność wykazują sieci scentralizowane.

Kolejną formą komunikowania się w grupie jest „winorośl”, czyli nieformalna sieć komunikacji wśród ludzi należących do organizacji; może przenikać całą organizację i nie zawsze odpowiada wzorcowi formalnych kanałów komunikacji. Badania pozwoliły zidentyfikować kilka rodzajów „winorośli”. Do najbardziej rozpowszechnionych należą łańcuch plotki i łańcuch kiści. Łańcuch plotki powstaje wówczas, gdy jakaś osoba upowszechnia wiadomość - najczęściej informację osobową - wielu innym ludziom. Każda $\mathrm{z}$ nich może zachować informację dla siebie lub podać ją dalej. Innym powszechnym typem „winorośli" jest łańcuch kiści, w którym jedna osoba przekazuje informację wybranym kilku osobom. Niektórzy odbiorcy przekazują informację kilku innym, reszta zachowuje ją dla siebie. $Z$ badań wynika że, informacja przekazywana przez „winorośl” może być dokładna w 75-95\% i jej rola systematycznie wzrasta. Próby wyeliminowania „winorośli" skazane są na niepowodzenie, ale na szczęście menedżer może ją kontrolować (np. może reagować na informacje nie odpowiadajace prawdzie).

$\mathrm{Na}$ uwagę zasługuje jeszcze kilka innych rodzajów komunikacji grupowej i organizacyjnej. Jedną z nich, która ostatnio zdobyła dużą popularność, jest zarządzanie przez krążenie po firmie. Podstawowa jej idea polega na tym, że menedżer utrzymuje kontakt $\mathrm{z}$ tym, co dzieje się w firmie, krążąc po terenie i rozmawiając $\mathrm{z}$ bezpośrednimi podwładnymi lub pracownikami znajdującymi się dużo niżej w hierarchii służbowej, dostawcami, klientami i wszystkimi, którzy w jakiś sposób związani są z firmą.

Inną formą komunikowania się $\mathrm{w}$ organizacji jest nieformalna wymiana dokonująca się poza normalnym środowiskiem pracy, zwykle w kontekście grup nieformalnych lub grup interesu (np. rozmowy na tematy zawodowe podczas pikniku, po zajęciach sportowych).

\section{Znaczenie komunikowania niewerbalnego w zarządzaniu firmą}

Komunikowanie nie ogranicza się tylko do słów. Wiele informacji przesyłanych jest cisza, ekspresją twarzy, ruchami ciała czy tonem głosu. Wyważone oceny zakładaja, że około $65 \%$ komunikowania ma charakter niewerbalny, podczas gdy na przekaz werbalny przypada tylko $35 \%$. 
Komunikowanie niewerbalne jest potężna, ale mało docenianą formą komunikowania w organizacjach. Obejmuje sygnały pozbawione słów lub je uzupełniające. Przekazami niewerbalnymi są wszystkie sygnały występujące w międzyosobowej interakcji, które nie mają ani formy mówionego słowa, ani pisanego wyrazu i obejmują wszystkie inne przekazy, które wywierają pewien wpływ na jej uczestników. nia":

Większość badaczy uznaje następujące kategorie niewerbalnego zachowa-

- aparycja (ubranie, uczesanie, makijaż, przybranie i ozdoby; cechy takie, jak: fizjonomia, waga, tusza i wzrost);

- kinezyka (ruchy ciała: gestykulacja, mimika twarzy, ruchy tułowia i kończyn, pozy, wzrok, spojrzenia);

- proksemika - wykorzystanie interpersonalnego dystansu i relacji przestrzennych;

- haptyka (dotyk) - przekazywanie sygnałów przez różne formy bezpośredniego kontaktu fizycznego;

- parajęzyk (wysokość, głośność, tempo, przerwy wokalne, modulacja);

- chronemika (czas oczekiwania, czas trwania, ilość spędzonego z kimś czasu).

Sceneria komunikacji, która obejmuje granice i znajomość miejscowego gruntu, odgrywa ważną rolę w komunikowaniu niewerbalnym. Na przykład wielkość i położenie biurka, rodzaj mebli biurowych i dostępność osoby w biurze przynoszą bardzo użyteczne informacje. Biurko może być ustawione tak, że podwładny siedzi zawsze naprzeciwko przełożonego, wówczas menedżer ma przewage nad pracownikiem. Jeśli natomiast rozmowa przyjmuje charakter mniej formalny, dyrektor może przejść na drugą stronę i usiąść obok gościa.

Duże znaczenie w komunikowaniu niewerbalnym ma również dystans interpersonalny, a więc odległość, w jakiej znajdujemy się od rozmówcy. W kontaktach przełożony - podwładny powinniśmy utrzymywać dystans społeczny, a więc stawać $\mathrm{w}$ odległości od $120 \mathrm{~cm}$ do $350 \mathrm{~cm}^{10}$. Na przykład w Stanach Zjednoczonych, jeśli ktoś stoi bardzo blisko rozmówcy, świadczy to o zażyłości lub agresji. Anglicy i Niemcy przywykli do jeszcze większego fizycznego dystansu w czasie rozmowy niż Amerykanie, podczas gdy Arabowie, Japończycy i Meksykanie lubią stać bliżej siebie podczas rozmowy.

Innym skutecznym środkiem komunikowania niewerbalnego jest kontakt wzrokowy. Dłuższy kontakt wzrokowy może sugerować zainteresowanie lub wrogość. Może być wykorzystany jako prezentacja siły. Gdy menedżer patrzy surowym, przenikliwym wzrokiem lub przeszywa rozmówcę spojrzeniem,

\footnotetext{
${ }^{9}$ W. Głodowski: op. cit., s. 152.

${ }^{10}$ P.J. Dąbrowski: Praktyczna teoria negocjacji. Wydaw. „Sorbog”, Warszawa 1991, s. 32.
} 
większość osób zaczyna czuć się nieswojo i pragnie uniknąć intensywnych, bezpośrednich spojrzeń. Są one demonstracją siły i władzy. Nieprzerwane natarczywe wpatrywanie sie jest zwykle interpretowane jako sygnał asertywności lub chęci dominacji. Unikanie kontaktu wzrokowego sygnalizuje chęć respektowania czyjejś prywatności. Może także oznaczać brak zainteresowania osobą, rozmową lub innymi wizualnymi przekazami.

Bardzo wymownym i często stosowanym gestem w układzie zwierzchnik podwładny jest „wzniesiona wieża"1! Ten fascynujący układ rąk wskazuje na pewność siebie albo postawę „Wszystko wiem”. Menedżerowie często stosują tę figure, gdy wydają polecenia lub rady podwładnym. Jest on szczególnie popularny wśród księgowych, prawników, dyrektorów itp.

Do elementów charakteryzujących język ciała należą także ruchy ciała i ramion, sposób ubierania się czy formułowania wypowiedzi. Jak cię widza tak cię pisza, dlatego menedżer powinien dbać o schludny wygląd, pamiętać o dosțosowaniu ubioru do pory dnia i okoliczności. Mężczyzna wychodząc do pracy wkłada ubranie spacerowe, udając się na koncert lub uroczystą kolacje ubranie wizytowe, a wyjeżdżając na wczasy - strój weekendowy lub ubranie sportowe koordynowane. Kobieta do pracy, podczas podróży i spacerów nosi kostium, natomiast na uroczystą kolację po godzinie 19.00 powinna włożyć sukienkę wizytową ${ }^{12}$.

Menedżer powinien być świadomy znaczenia komunikowania niewerbalnego i rozumieć jego potencjalny wpływ na skuteczność porozumiewania się. Na przykład przekazanie pracownikowi pomyślnej nowiny o nagrodzie, której towarzyszą przeciwstawne $\mathrm{w}$ treści sygnały niewerbalne, może zrujnować wartość wzmocnienia, jaka tkwi w nagrodzie. Podobnie udzielenie nagany $\mathrm{z}$ wykorzystaniem niewłaściwych sygnałów niewerbalnych może ograniczyć skuteczność sankcji. Zarówno ton wypowiedzi, sposób i okoliczności jej przekazania, jak i wyraz twarzy, postawa ciała czy gestykulacja mogą wzmocnić, osłabić lub zmienić znaczenie informacji.

\section{Bariery skutecznego komunikowania się}

Uwzględniając uwarunkowania wewnętrzne wypowiedzi, tj. uwarunkowania psychologiczne uczestników oraz uwarunkowania zewnętrzne, wyróżnia się trzy kategorie barier komunikacyjnych ${ }^{13}$ :

\footnotetext{
${ }^{11}$ A. Pease: Mowa ciała. Wydaw. Jedność, Kielce 2001, s. 46.

${ }^{12}$ Por. E. Pietkiewicz: Etykieta menedżera. Wydaw. Twój Styl, Warszawa 1993, s. 63 i A. Wiszniewski: Jak przekonująco mówić i przemawiać? PWN, Warszawa-Wrocław 1994, s. 108.

${ }^{13}$ W. Głodowski: op. cit., s. 26 i E. M. Cenker: op. cit., s. 42.
} 
- bariery semantyczne (zniekształcanie informacji, zbyt duża liczba informacji, niezrozumiała tematyka, problemy ze zrozumieniem terminologii lub jezzyka wypowiedzi);

- bariery psychologiczne (negatywne nastawienie, nieśmiałość, brak zainteresowania problemem, nadmierne zaangażowanie emocjonalne, lekceważenie słuchaczy, brak przygotowania merytorycznego, brak koncentracji uwagi, monotonna wypowiedź, zmęczenie, brak umiejętności aktywnego przysłuchiwania się);

- bariery fizyczne $\mathbf{i}$-środowiskowe (hałas, nieodpowiednie: temperatura, miejsce, pora dnia, problemy techniczne, zbyt duża liczba uczestników, presja czasu).

Źródłem zakłóceń w procesie komunikowania może być:

- nadawca, który nie zawsze wie, co właściwie chce powiedzieć,

- wiadomość, która może być sformułowana zbyt wieloznacznie lub zbyt prosto,

- kanał, który może skracać lub poszerzać informację,

- odbiorca, a w zasadzie jego psychofizyczna kondycja w momencie odbioru informacji,

- zasób znaków, jeśli wykorzystuje się nieznane pojęcia lub niezrozumiałe dla obu partnerów sposoby prezentacji,

- oczekiwania; im bardziej są rozbieżne, tym więcej powstaje zakłóceń komunikacyjnych.

Obok zakłóceń związanych z samą wiadomością i systemem znaków, istnieją także zakłócenia wynikające $\mathrm{z}$ funkcjonowania mechanizmów selekcyjnych. Powodują one, że informacja nie dociera do odbiorcy lub w wyniku ich działania dociera zniekształcona.

A.W. Van den Ban ${ }^{14}$ wyróżnił siedem mechanizmów selekcyjnych, a mianowicie: selektywne wysyłanie, selektywne postrzeganie, selektywną uwagę, selektywne opracowywanie, selektywne zapamiettywanie, selektywne akceptowanie i selektywne rozmawianie o tym $z$ innymi. Pozwala to na sformułowanie kilku instruktażowych stwierdzeń dotyczących możliwości komunikowania:

$\begin{array}{lll}\text { powiedział } & \text { to jeszcze nie znaczy } & \text { słyszał } \\ \text { słyszał } & \text { to jeszcze nie znaczy } & \text { usłyszał } \\ \text { usłyszał } & \text { to jeszcze nie znaczy } & \text { zrozumiał } \\ \text { zrozumiał } & \text { to jeszcze nie znaczy } & \text { zaakceptował } \\ \text { zaakceptował } & \text { to jeszcze nie znaczy } & \text { działał }\end{array}$

${ }^{14} \mathrm{H}$. Boland: Podstawy komunikowania w doradztwie. Wydaw. CDiEwR, Poznań 1995 (thum. E. Jaska), s. 36-37. 
Instruktażowe stwierdzenia mają szerokie, praktyczne zastosowanie. Menedżer, który przekazuje polecenia podwładnym, prowadzi rozmowy, organizuje zebrania czy konferencje, powinien pamiętać o istnieniu barier utrudniających proces komunikowania. Dobra informacja zwrotna oraz umiejętność aktywnego przysłuchiwania się moga poprawić skuteczność komunikowania interpersonalnego.

\section{Informacja zwrotna jako technika poprawy skuteczności komunikowania}

Jednym $\mathrm{z}$ ważniejszych elementów decydujących o powodzeniu w procesie komunikowania jest informacja zwrotna, czyli sprzężenie zwrotne (,feedback”, a w języku niemieckim „meldunek zwrotny"). N. Wiener ${ }^{15}$ sformułował następującą tezę: "Wiem co powiedziałem, dopiero wtedy, gdy otrzymałem na to odpowiedź".

W procesie komunikowania zawsze przekazywana jest informacja zwrotna w formie werbalnej lub niewerbalnej. Jest to jednak feedback warunkowy, który wymaga interpretacji, a tym samym zawiera sam w sobie źródło błędu i tylko $\mathrm{w}$ niewielkim stopniu niweluje nieporozumienia. Szczególnie przydatny w procesie komunikowania się jest feedback objaśniający, czyli wyjaśnienie tego, co dokonało się we mnie podczas wypowiedzi. Taki feedback nie posuwa rozmowy zbyt szybko do przodu, działa nawet hamująco. Umożliwia jednak wyjaśnienie nieporozumień na początku i ich usunięcie. Jest szczególnie ważny wówczas, gdy dostarcza informacji ważnych dla mnie lub mówiących o mnie. Feedback powinien być przekazywany w formie „Ja - wiadomośč”. Taka wypowiedź jest szczera, nie jest oparta na porównywaniu i nie podlega dyskusji. Formułując natomiast „wiadomość - Ty" najczęściej sugeruję coś mojemu rozmówcy, ukrywam to, co dokonało się we mnie i tym samym stwarzam okazję do dyskusji na temat wypowiedzi. Nieporozumienia należy wyjaśniać na bieżąco, nie czekać z informacjami zwrotnymi zbyt długo, aby nie dopuścić do „wybuchu wulkanu”. Jeśli jest to tylko możliwe, należy przekazywać feedback pozytywny. Wówczas feedback negatywny jest lepiej odbierany przez partnera. Negatywne wypowiedzi oprócz tego, że nie rozwiązują problemów, to jeszcze dodatkowo niszczą pozytywne relacje z innymi ludźmi.

${ }^{15}$ H. Boland: op. cit., s. 57. 


\section{Aktywne słuchanie jako czynnik zapewniający skuteczne komunikowanie się}

Słyszenie jest procesem automatycznym przebiegającym pasywnie, natomiast słuchanie stanowi reakcję dobrowolną świadoma, wykonywaną aktywnie. Wyróżnia się dwa sposoby słuchania: nierefleksyjne i refleksyjne. Słuchanie nierefleksyjne stanowi najprostszą formę słuchania. Towarzyszy mu mimowolne przejawianie reakcji ustnych typu: „uhm”, „aha” i zachowywanie „uważnej ciszy”. Pozbawione jest osądów i rad. W sposób nierefleksyjny menedżer powinien wysłuchać podwładnego w sytuacji, gdy jest on skłonny opowiedzieć o swoich zamiarach, poglądach czy propozycjach (np. rozmowy kwalifikacyjne, wysłuchanie skarg, zażaleń czy propozycji). Jeśli pracownik oczekuje aktywnej formy wsparcia lub nie jest dostatecznie skłonny do mówienia, wówczas słuchanie nierefleksyjne staje się niewystarczające. Aby precyzyjnie porozumieć się z rozmówca, menedżer powinien wysłuchać go w sposób refleksyjny. Jest to taki rodzaj uczestnictwa w procesie komunikowania za pomocą słów, w którym słuchacz odzywa się do mówcy w sposób pozbawiony jakichkolwiek osąów. Robi to tylko po to, aby sprawdzić, czy właściwie zrozumiał to, co zostało powiedziane. Słuchanie refleksyjne charakteryzują cztery podstawowe rodzaje reakcji: wyjaśnianie, parafrazowanie, odzwierciedlanie emocji i uczuć oraz podsumowywanie.

Aktywnemu słuchaniu powinny towarzyszyć umiejętnie zadawane pytania. Celem takich pytań jest uświadomienie rozmówcy, że nie w pełni rozumiemy to, co przed chwilą powiedział. Ważne jest, aby pytania dotyczyły treści bądź formy przekazu, a nie osoby mówcy. Pytania takie są ważne, ponieważ nadawca informacji nie zdaje sobie sprawy z tego, że wyraża się niejasno.

Jedną z najbardziej przydatnych metod aktywnego słuchania jest umiejętność parafrazowania ${ }^{16}$. Jej istota jest powtarzanie sensu ostatniej wypowiedzi rozmówcy, w celu sprawdzenia, czy została ona właściwie zrozumiana. Ważne jest, aby podczas parafrazowania nie interpretować usłyszanej wypowiedzi, ale tylko przedstawić ją za pomocą własnych słów. Ponadto parafrazowanie sugeruje rozmówcy, że jest słuchany $z$ uwagą $i$ zainteresowaniem. Przydatne $w$ parafrazowaniu sq̨ takie sformułowania rozpoczynające wypowiedź, jak: „O ile dobrze zrozumiałam, to ...”, „Chce Pani powiedzieć, że ...”. Tego typu zdania pozwalają dokładnie powtórzyć usłyszaną wcześniej informację.

Odzwierciedlanie emocji i uczuć jest umiejętnością wymagającą dużej wprawy. Polega ono na tym, że odbiorca dostosowuje się w zachowaniu, spo-

\footnotetext{
${ }^{16}$ E.M. Cenker: Negocjacje. Wydaw. Wyższej Szkoły Komunikacji i Zarządzania. Poznań 2002, s. 43-46.
} 
sobie mówienia, a nawet $w$ głębszych procesach dotyczących odbioru i przetwarzania informacji do swojego odbiorcy. Menedżer wykorzystujący tę umiejętność odwzorowuje wewnętrzny i zewnętrzny świat swojego rozmówcy, dzięki czemu proces komunikacji zachodzi w najbardziej pełny sposób. Umiejętność odzwierciedlania jest bardzo ważna w sytuacjach, kiedy w procesie komunikowania występują problemy, rozmówcy mają wrażenie, że nie mówią tym samym językiem.

W celu zebrania usłyszanych treści w spójną całość oraz sprawdzenia, czy właściwie zrozumieliśmy to, co zostało powiedziane dotychczas, robimy podsumowanie. Jest ono wskazane w dyskusjach, konfliktach, przy wysłuchiwaniu skarg i zażaleń oraz w rozmowạch $\mathrm{z}$ ludźmi gadatliwymi.

\section{Podsumowanie}

Komunikowanie jest ważną częścią pracy menedżera. Proces komunikowania się składa się z kodowania treści przez nadawcę i przekazywania jej jednemu lub kilku odbiorcom, którzy otrzymują wiadomość i rozszyfrowują jej treść. W procesie dwustronnego komunikowania się czynności te powtarzają się, a role nadawcy i odbiorcy są wymienne.

Istnieje duża różnorodność form komunikowania się w organizacji. W układzie pionowym komunikacja odbywa się pomiędzy przełożonymi i podwładnymi zarówno w góre, jak i w dół. Komunikacja w poziomie obejmuje osoby na równorzędnych stanowiskach. Członkowie grupy powiązani są ze sobą według powtarzalnego wzorca, zwanego siecią komunikacyjną. Nieformalną sieć komunikacyjną pomiędzy członkami organizacji określamy mianem „winorośli".

Kierowanie procesem komunikowania się $\mathrm{w}$ przedsiębiorstwie wymaga rozpoznania barier skutecznej komunikacji i sposobów ich pokonywania. Przydatna w tym zakresie może być umiejętność przekazywania komunikatów werbalnych zgodnych z sygnałami niewerbalnymi, a także umiejętność aktywnego przysłuchiwania się oraz odbierania informacji zwrotnej. 


\section{The Manager's Communicational Competence as a Factor of an Effective Management of a Company}

\section{Abstract}

Concepts of communication, forms of communication, verbal and unverbal communication in an enterprise are presented in the article. They determine an effective management of a company.

The management of the communication process in a company requires: reconnaissance of barriers to effective communication and finding methods to overcome them. Abilities of reading unverbal signals, sending verbal signals consistent with unverbal signals and ability of active listening and reading feedback are very useful in this field. 
